\title{
Intrinsic motivation for creativity of agricultural holdings in Kirşehir province of Turkey
}

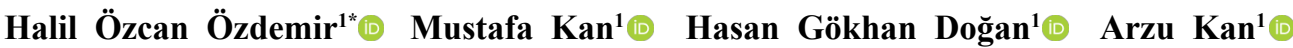

${ }^{1}$ Kırşehir Ahi Evran University, Agricultural Faculty, Department of Agricultural Economics, Kırşehir, Turkey. E-mail: hoozdemir@ahievran.edu.tr. ${ }^{*}$ Corresponding author.

ABSTRACT: The agriculture sector which has gained importance with Industry 4.0 in recent years, strives to adapt to the needs and requirements of the era by stripping from its traditional structure. In this process, it is important to increase the motivation (intrinsic and extrinsic) of human resources factor, which is the most important input of agriculture, on innovation, creativity and entrepreneurship. This paper examined the factors that affect the intrinsic motivation of the agricultural holdings managers in Kirsehir province of Turkey on their creativity for innovation, which is one of the main variables of growth. Questionnaire forms were filled with 312 agricultural holdings managers who were selected according to the Probability Sampling Method in September-October, 2019. Intrinsic motivation scores for creativity (IMC) were obtained by using 5-point scale. Determined some socio-demographical, agricultural, economic and behavioral variables for agricultural holdings were tested with IMC levels. As a result of the study, it was determined that variables such as education, social security status, share of agricultural income, subjective poverty and risk behaviors significantly affect the IMC level of the agricultural enterprise managers. As a result, the measures to increase both the internal and external motivations of the agricultural enterprises managers are required in order to make agriculture more competitive, profitable and sustainable by removing it from the traditional structure. In this regard, not only the economic side but also the social side of agriculture should not be ignored and the potential of agriculture should be used more with structural reforms.

Key words: creativity, motivation, agricultural management, organisational behaviours, Kirsehir-Turkey.

Motivação intrínseca à criatividade de empresas agrícolas na província de Kirşehir, na Turquia

RESUMO: O setor agrícola, que ganhou importância com a Indústria 4.0 nos últimos anos, esforça-se por se adaptar às necessidades e exigências da época retirando sua estrutura tradicional. Nesse processo é importante aumentar a motivação do fator recursos humanos, que é o insumo mais importante da agricultura, em inovação, criatividade e empreendedorismo. Com este estudo, tentou-se revelar os fatores que afetam a motivação dos gerentes de empresas agrícolas na província de Kirsehir, na Turquia, sobre inovação e criatividade, que é uma das principais variáveis de crescimento. Os formulários do questionário foram preenchidos com 312 gerentes de empresas agrícolas, selecionados de acordo com o Método de Amostragem por Probabilidade. Os escores de motivação intrínseca para a criatividade (IMC) foram obtidos usando a escala de cinco pontos. Determinou-se que algumas variáveis sociodemográficas, agricolas, econômicas e comportamentais para explorações agrícolas foram testadas com os niveis de IMC. Como resultado do estudo, foi determinado que variáveis como educação, status de seguridade social, parcela da renda agricola, pobreza subjetiva e comportamentos de risco afetam significativamente o nivel de IMC dos gerentes de empresas agrícolas. Como resultado, são necessárias medidas para aumentar as motivações internas e externas dos gerentes de empresas agrícolas, a fim de tornar a agricultura mais competitiva, rentável e sustentável, removendo-a da estrutura tradicional. Nesse sentido, não apenas o lado econômico, mas também o lado social da agricultura não devem ser ignorados e o potencial da agricultura deve ser mais utilizado nas reformas estruturais.

Palavras-chave: criatividade, motivação, gestão agrícola, comportamentos organizacionais, Kirsehir-Turquia.

\section{INTRODUCTION}

The survival of businesses seems to depend on their persistence in innovation. Having innovative skills is the prerequisite and reason for the businesses to create competitive advantage. A contrary strategy means that the business will not be able to benefit from the peripheral opportunities in the long term.
The business that cannot benefit from such peripheral opportunities may be affected adversely from risks. The word "innovation" refers sometimes to "a new product" and sometimes to "development process of a new product" (VERHEES \& MEULENBERG, 2004). Therefore, the word "innovation" is translated to Turkish with the word "yenilik" (novelty) to express the outcome and with the word "yenilikçilik" 
(innovativeness) to express the process (SUNGUR et al., 2014).

The prerequisite for organizational success and market leadership is to create consistent novelties. Innovation brings into force the customer satisfaction oriented organizational behaviour patterns on one hand and serves the function of maintaining the continuity of an organization (BARKER, 2001).

Innovation is considered to be continuous, dynamic and radical novelties. Continuous novelty refers to small changes by organizations in their products in accordance with the customer needs and pleasure without total changes in the structure of the products. Dynamic novelty includes the development of a new product or a new type of an existing product without changing the usage habits of products. Radical novelty is the production of a new product that changes the usage habits of customers (BARIŞIK, 2001; DEMİREL \& SEÇKIN, 2008).

Innovation works have existed since the first civilizations. This is particularly demonstrated by the archaeological findings of tools that were used in hunting and agriculture. Until the 19th century, soil cultivation was done with wooden plough and harvesting was done with reaping hook while today they are carried out by modern tractors and planting machines and combine harvesters respectively. Innovation is the most important factor to become competitive in the sectors of agriculture, industry and service.

Creativity is related to the skills of problem solving, decision making and self-expression. At the same time, it is the intellectual skill that is the basis of innovation. Creativity is the first step in the innovation process; and is therefore, a critical foundational element of the innovation process (CROPLEY, 2006). There are three components needed to be creative (ROBBINS \& JUDGE, 2013): (1) competency, which means knowledge plus abilities plus attitudes in their work field; (2) creative thinking abilities, such as intelligence, independence, risk taking, self-control, tolerance to ambiguity and avoiding frustration; and (3) intrinsic motivation in the assignments, which refers to interesting, intensive and emoting work.

Motivation is an indication of the willingness of a person to act for a certain goal while creativity is an indication of the effort spent to achieve a specified goal. The word "motivation" is derived from the word "motive" and it is described by NELSON \& QUICK (2003) to be a process of creating and maintaining goal oriented behaviour; by LUTHANS (1992) to be a physiological or psychological requirement that initiates the behaviour or motive for a purpose and by Robbins (1996) to be the willingness of employees to spend great effort to achieve organizational goals depending on the fulfilment of their individual needs. Increasing the motivation is one of the key component to foster creativity and also innovation to get success in business life.

When we compare the organizational structure of different type of sectors in business, agricultural holdings are different compared to nonagricultural enterprises. Almost all agricultural holdings in developing countries such as Turkey, consists of family farms. In these businesses, both the employee and the entrepreneur are mostly family members. Therefore, employee-boss relationship differs from nonagricultural enterprises. The success and sustainability of a business is closely related to the vision of the operator. Studies have shown that creativity and innovation are effective in the competitiveness, performance, product quality and efficiency of the organization (ANDERSON et al., 2014; LIU et al., 2016) While this structure depends on the creative ideas and innovative impulses of both the employee and the entrepreneur himself/herself, this situation mostly depends on the person who is the head of the household and who is the head of the agricultural holding.

With respect to the agriculture system, innovation can be evaluated within a broad spectrum from the production of a product to the production technology and marketing of the product. It is seen that industrialized countries have achieved significant developments in the agricultural sector through innovation. The agricultural innovation process has been increasingly institutionalized in developed countries for the last two centuries. Agricultural ministries, universities, research stations, publication organizations and industrial R\&D departments have been established within the scope of public, semipublic and private sectors. As a result, societies carried out significant investments for creating complex institutional arrangements to advance technological innovation in agriculture and particularly after the World War II, agricultural production reached to unprecedented levels due to both "scientification" and industrialization (ENGEL, 1994; UYAN, 2018).

Intrinsic and extrinsic motivation are important factors in ensuring competitiveness and creating innovation and creativity features of businesses. Intrinsic motivation is known as autonomous choice, whilst extrinsic motivation is controlled choice of the people (MOLLER et al., 2006). The motivation of the producers is important for productivity in agriculture and adaptation to new technologies especially in developing countries and where small agricultural business is dominant. Motivation for the smallholder 
farmers to adopt management of natural resources in a sustainable way is one of the important ways to tackle low productivity and yield (KASSIE et al., 2013). In cases where intrinsic motivation is higher, it is stated that adaptation to new technologies and continuity of using these technologies are higher. (CHIRKOV et al., 2003, MOLLER et al., 2006). MWAIJANDE stated that when farmers are intrinsically motivated, they are driven by interest, satisfaction and enjoyment of the activity itself.

There are limited studies in the literature on motivation that develops innovation and creativity in agricultural holdings in Turkey. SUBAŞI \& ÖREN (2013) determined a long term relation between R\&D researches and agricultural growth. SUNGUR, KOÇ \& DULUPÇU (2014) conducted a study on the analysis on the innovation and cooperation with local actors of the agriculture companies and agriculture related companies and reported that the companies substantially carried out the innovation activities by themselves and didn't cooperate with another company. UYAN (2018) stated that Turkey didn't make sufficient use of its agricultural potential and that the way to increase added value, revenue, income and quality and reduce costs in agriculture would be through innovation in agriculture.

One of the aims of Turkey's agricultural policy is to increase competitiveness in agriculture
(OFFICIALGAZETTE, 2006). Oneofthemostimportant keys to competitiveness is the promotion of innovation in agriculture. The word innovation is more used for agricultural firms that process agricultural products and turn them into finished and semi-finished products. But the formation of a competitive agricultural sector is driven by the creation of a productive society with innovative, entrepreneurial spirit and creative ideas. Therefore, it is important to examine the agricultural holdings that produce raw materials in the agricultural sector in terms of intrinsic and extrinsic motivations. This study aimed to determine the levels of intrinsic motivation for innovation in agricultural holdings operating in the province of Kırşehir and its districts. The study also intends to provide contribution to the literature and to those who would study on innovation in agricultural holdings.

\section{MATERIALS AND METHODS}

\section{Study area and data collection}

The main material of the study consists of the data obtained from the questionnaire forms filled by the farmers registered to the Farmers Register System and/ or Veterinary Register System in total 6 districts of the Kurşehir Province (Centrum, Mucur, Kaman, Boztepe, Akçakent, Akpınar, Çiçekdağı) (Figure 1) between November and December 2019. Kırşehir is located in

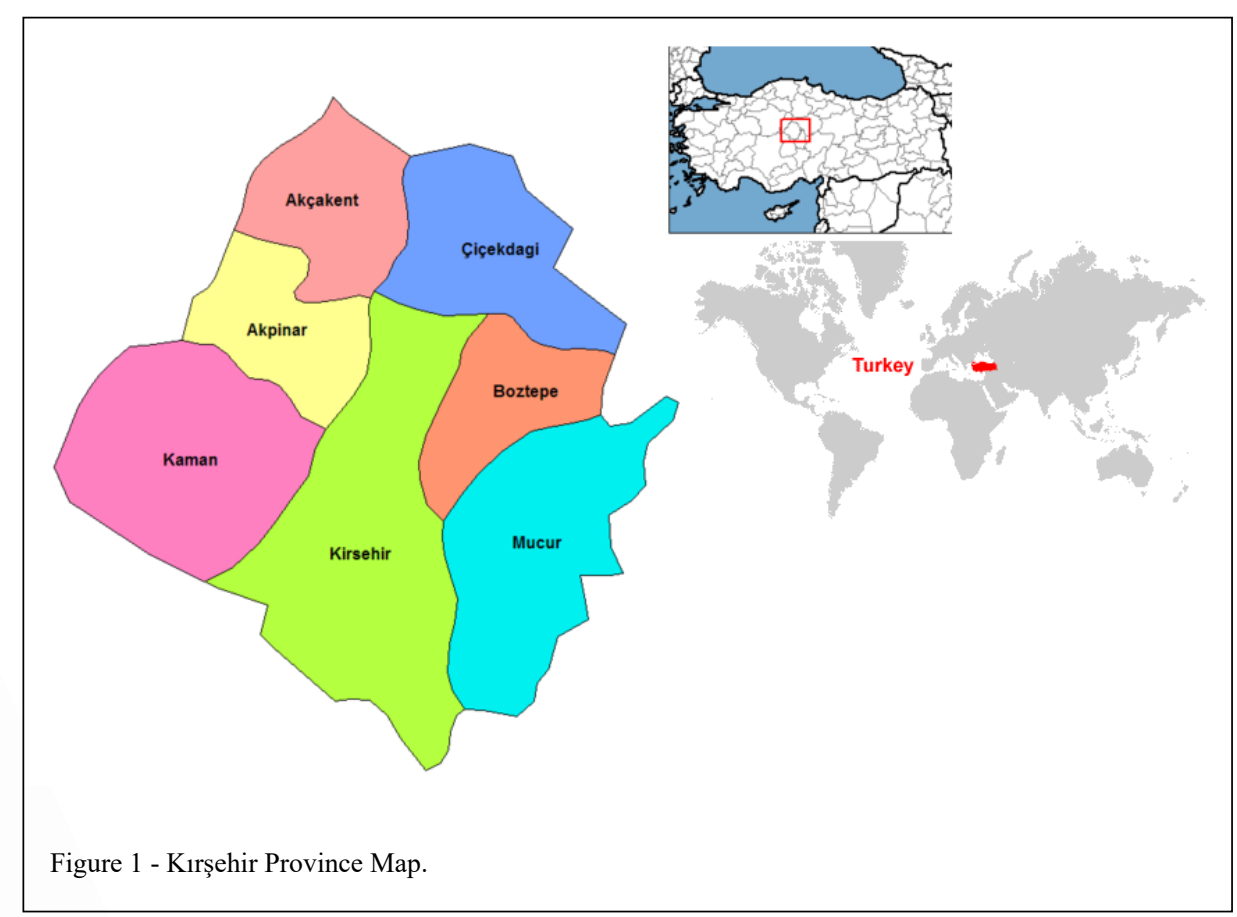

Ciência Rural, v.51, n.3, 2021. 
Turkey's Central Anatolia Region, Middle Kizılırmak Basin. 90\% of the province's agricultural land is dominated by dry farming system. It is one of the provinces with significant potential in cereal, legume and red meat production. Forty-two percent of the population lives in rural areas. Since the realization of interest in rural areas is not cut by urbanization, the rate of the population in agriculture is quite high. Approximately $65 \%$ of the working population is employed in agriculture (KTOİ, 2019). In the province where agricultural potential and agriculturebased lifestyle is widespread, it is important to use the available resources more efficiently and to support agricultural entrepreneurship in order to reach the desired level in agricultural production. In addition, national and international publications on the matter were collected and used as secondary resources in the study.

\section{Sampling}

The primary condition of being officially recognized to be a farmer is the registration in one of the registry systems of the Ministry of Agriculture and Forests. The most important farmers' data base in Turkey is the Farmers Register System (FRS) and Veterinary Register System (VRS). FRS covers the farmes dealing with vegetative production while VRS covers the farmers dealing with animal production. The use of this database is important in determining population while selecting sample in the studies with farmers. There are total 19,934 farmers registered in all districts of the Kırşehir Province (Table 1). Therefore, the main population of the study consists of these farmers. The Probability Sampling Method was used in determining the sample to represent the Kırşehir province and its districts. The $\mathrm{p}$ and $\mathrm{q}$ ratios were determined to be 0.5 to reach the maximum number of sample as the concerned ratios were not certain. Proportional Sampling Method was used to determine the sample size by using the formula (YAMANE, 2001);

$$
\begin{aligned}
& \mathrm{n}=\frac{\mathrm{N} * \mathrm{p} *(1-\mathrm{p})}{(\mathrm{N}-1) * \sigma_{p}^{2}+\mathrm{p} *(1-\mathrm{p})} \\
& \sigma_{p}^{2}=\left(\frac{r}{Z_{\alpha / 2}}\right)
\end{aligned}
$$

In the formula; $\mathrm{n}$ : Sample size, $\mathrm{N}$ : Number of enterprises in the population, $\sigma_{p}^{2}$ : Variance of the ratio, r: Permissible margin of error $(5 \%), Z_{\alpha / 2}$ : The ruler value of $\mathrm{z}(1.65) \mathrm{p}$ : Indicates the possibility of IMC for farmers within the population. The number of farmers to be surveyed was determined as 273 with $90 \%$ reliability $(\mathrm{z}=1.65)$ and $5 \%$ deviation from the average. We considered $15 \%$ additional farmers to survey and in total 312 farmers have included to the research (Table 1). The survey was conducted in September-October 2019 and the heads of agricultural holdings were determined randomly by considering the reflecting of the population. The questionnaire forms were formed by structured questions and were fulfilled by face to face method with the head of agricultural holdings.

\section{Data analysis}

Intrinsic motivation scores for creativity were obtained by using the scale improved by Tierney et al. (1999) on a 5-point scale (YUAN \& WOODMAN 2010). Each employee indicated the extent to which he or she agrees with each statement about himself or herself as a person $(1=$ strongly disagree; $5=$ strongly agree). The scale parameters (questions) have been presented in table 2 .

\begin{tabular}{|c|c|c|c|c|}
\hline $\begin{array}{l}\text { Districts of } \\
\text { Kirsehir } \\
\text { Province }\end{array}$ & $\begin{array}{l}\text { The Number of Farmers } \\
\text { Recorded in Farmers } \\
\text { Record System (FRS) in } \\
2019\end{array}$ & $\begin{array}{l}\text { The Percentage of Farmers } \\
\text { in Total Farmers }(\%)\end{array}$ & $\begin{array}{l}\text { The Distrubition of } \\
\text { Sample Size By Districts }\end{array}$ & $\begin{array}{c}\text { The Study Sample Size By } \\
\text { Districts ( } 15 \% \text { more })\end{array}$ \\
\hline Akçakent & 1115 & 5.59 & 15 & 17 \\
\hline Akpınar & 2051 & 10.29 & 28 & 32 \\
\hline Boztepe & 2132 & 10.70 & 29 & 33 \\
\hline Çiçekdağ & 3005 & 15.07 & 41 & 47 \\
\hline Kaman & 4306 & 21.60 & 59 & 67 \\
\hline Merkez & 3911 & 19.62 & 54 & 62 \\
\hline Mucur & 3414 & 17.13 & 47 & 54 \\
\hline Total & 19934 & 100.00 & 273 & 312 \\
\hline
\end{tabular}

Table 1 - The Distrubution of Sample Size By The Districts of Kirsehir Province. 
Table 2 - The IMC Scale Questions.

\begin{tabular}{lc}
\hline & \\
\hline 1 & I enjoy finding solutions to complex problems \\
2 & I enjoy coming up with new ideas for products \\
3 & I enjoy engaging in analytical thinking \\
\hline 4 & I enjoy creating new procedures for work tasks \\
\hline 5 & I enjoy improving existing \\
\hline
\end{tabular}

With the data obtained from the IMC Scale questions, factor scores were created by factor analysis and IMC levels were grouped as Low, Medium and High IMC through these factor scores. The relationship between IMC level and the examined variables in the research which are Socio-Demographical Variables (Age, Education, Marital Status, Social Security), Agricultural Variables (Agricultural Farm Types, Agricultural Satisfaction, Land ownership, Experinces in agriculture and Working days), Economic Variables (Subjective Poverty) and Behavioral Variable (Risk Behavior) of agricultural holdings' managers were statistically tested.

In order to evaluate the data obtained from the surveys applied in the field with appropriate analysis methods, a database was created and the survey data was entered into this database. Since the sample did not show a normal distribution, nonparametric Chi-Square Independence tests were performed. The value of the test-statistic is; (KESICI \& KOCABAS, 2007).

$$
\chi^{2}=\sum_{i=1}^{n} \frac{\left(O_{t}-E_{i}\right)^{2}}{E_{i}}
$$

Where, $\chi 2=$ Pearson's cumulative test statistic, which asymptotically approaches a $\chi^{2}$ distribution, $\mathrm{Oi}=$ an observed frequency; $\mathrm{Ei}=$ an expected (theoretical) frequency, asserted by the null hypothesis; $n=$ the number of cells in the table. The maximum $20 \%$ of total cells' frequency values should be less than 5 in created cross-tables to accept the Chi Square analysis results as reliable and no cell frequency should fall below 1. When this limit is exceeded, the reliability of the results obtained from chi-square analysis shall be questioned. Therefore, where Chi-Square Analysis is not valid, "Likelihood Ratio" value was used. The data was tested according to 90, 95 and $99 \%$ of the confidence levels. In the analysis of continuous data, Variance Analysis was used from parametric tests (KESICI \& KOCABAS
2007) or Kruskall Wallis Test for non-parametric situation (DÜZGÜNEŞ et al., 1983).

\section{RESULTS AND DISCUSSION}

The motivation types included in the Self-determination Theory can be divided into two as "intrinsic motivation" and "extrinsic motivation" (DECI et al., 1996; RIGBY et al., 1992). Intrinsic motivation refers to the motivation that is inherent in individuals. People are instinctively motivated to do or not to do certain behaviours as intrinsic motivation is the connection of the relation between a person and a task. Those with high intrinsic motivation act for fun or for the necessity of struggle not because of external pressure or material rewards. Intrinsic motivation in humans is not only a form of motivation but also includes the will related behaviours. This tendency of natural motivation is a critical element in the cognitive, social and physical development of people (RYAN \& DECI, 2000).

DECI \& RYAN (1985) divided extrinsic motivation into two including extrinsic motivation with autonomous decision and extrinsic motivation without autonomous decision. Extrinsic motivation with autonomous decision refers to the actions of employees by their own choices without confronting any pressure. A person carries out an action if he or she considers that behaviour to be important. In extrinsic motivation without autonomous decision, employees believe that their behaviours are controlled by external factors and do that behaviour based on the fear of guilt if they don't do what is asked (KART \& GÜLDÜ, 2008).

The basic difference between intrinsic and extrinsic motivation is that the intrinsic motivation is naturally caused by the fact that an individual does what he or she likes or is interested in. In intrinsic motivation, employees act to get satisfaction in line with their interests while in extrinsic motivation, they act to get rewards or to avoid punishment. There are 
studies that reported significant differences in the performances of employees that act on the basis of intrinsic or extrinsic causes. Intrinsic motivation in organizations is resulted in high level of learning and creativity (WONG \& LADKIN, 2008).

This study examined the elements affecting intrinsic motivation covering the managers of agricultural holdings who are also workers of their own holdings in the province of Kırşehir. The workers of agricultural holdings can also be the owners and; therefore, their innovation works arise from their interest in innovation and their desire in innovative works, not from the wish to get a reward or to avoid punishment. In this scope, the elements that may affect intrinsic motivation are studied under 4 groups. These included socio-demographical variables, agricultural variables, economic variable and behavioural variable. Descriptive statistics of the variables have been presented in table 3 .

When we review table 3 , we can see that the agricultural holding owners have an average age of more than 50 years, are mostly primary school graduates, are married and almost half of them have non-agricultural coverage of social insurance. The situation shown by this data is greatly similar to the socio-demographical structure of the agricultural holdings of the Central Anatolian Region of Turkey in particular (OLHAN et al., 2010; OĞUZ et al., 2012; AHİKA, 2013; OZDEMIR \& KAN, 2020; OZDEMIR et al., 2020).

Table 3 - Descriptive Statistics of Agricultural Holdings.

\begin{tabular}{|c|c|c|c|c|c|}
\hline & -------Varia & ----------------- & Mean & Count & $\%$ \\
\hline \multirow{9}{*}{$\begin{array}{c}\text { Socio- } \\
\text { Demographical } \\
\text { Variables }\end{array}$} & 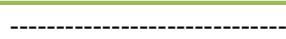 & 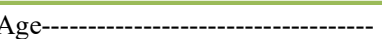 & 51.74 & & \\
\hline & \multirow{4}{*}{ Education } & Illiterate & & 17 & 5.48 \\
\hline & & Primary School & & 214 & 69.03 \\
\hline & & Secondary School & & 58 & 18.71 \\
\hline & & University & & 21 & 6.77 \\
\hline & \multirow{2}{*}{ Marital Status } & Married & & 279 & 89.71 \\
\hline & & Single & & 32 & 10.29 \\
\hline & \multirow{3}{*}{ Social Security } & No Social Security & & 41 & 13.31 \\
\hline & & Social Security for Farmers & & 114 & 37.01 \\
\hline \multirow{16}{*}{$\begin{array}{l}\text { Agricultural } \\
\text { Variables }\end{array}$} & & Others & & 153 & 49.68 \\
\hline & \multirow{3}{*}{$\begin{array}{c}\text { Agricultural Farm } \\
\text { Types }\end{array}$} & Only Crop Producers & & 109 & 30.13 \\
\hline & & Only Animal Growers & & 26 & 4.49 \\
\hline & & Both of Them & & 175 & 65.38 \\
\hline & \multirow{5}{*}{ Agricultural Satisfaction } & Never Satisfy & & 46 & 14.79 \\
\hline & & Non-Satisfy & & 58 & 18.65 \\
\hline & & Neutral & & 52 & 16.72 \\
\hline & & Satisfy & & 132 & 42.44 \\
\hline & & Very Satisfy & & 23 & 7.40 \\
\hline & \multicolumn{2}{|c|}{-------------Total Working Days in Agriculture (Days)------------ } & 14.35 & & \\
\hline & \multicolumn{2}{|c|}{ 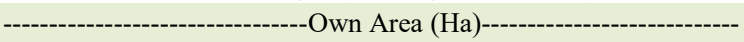 } & 12.14 & & \\
\hline & \multicolumn{2}{|c|}{ 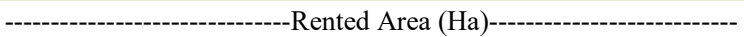 } & 4.19 & & \\
\hline & \multicolumn{2}{|c|}{ 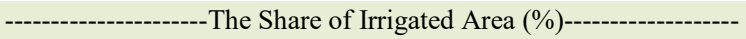 } & 22.42 & & \\
\hline & \multicolumn{2}{|c|}{ 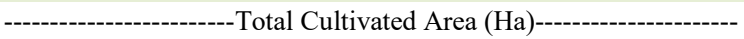 } & 16.33 & & \\
\hline & \multicolumn{2}{|c|}{------------------Experience in Crop Production (Year)------------- } & 26.41 & & \\
\hline & \multicolumn{2}{|c|}{----------------Experience in Animal Production (Year)------------ } & 24.60 & & \\
\hline \multirow{4}{*}{$\begin{array}{l}\text { Economic } \\
\text { Variables }\end{array}$} & \multicolumn{2}{|c|}{---------------The Share of Agricultural Income (\%)-------------- } & 43.90 & & \\
\hline & \multirow{3}{*}{ Subjective Poverty } & Poor & & 16 & 5.16 \\
\hline & & Medium & & 231 & 74.52 \\
\hline & & Good & & 63 & 20.32 \\
\hline \multirow{4}{*}{$\begin{array}{l}\text { Behavioral } \\
\text { Variable }\end{array}$} & \multirow{3}{*}{ Risk } & Risk Acceptant & & 119 & 38.51 \\
\hline & & Risk Neutral & & 40 & 12.94 \\
\hline & & Risk Averse & & 150 & 48.54 \\
\hline & \multicolumn{2}{|c|}{---------Intrinsic Motivation for Creativity Point (1-5 Scale)-------- } & 3.71 & & \\
\hline
\end{tabular}

Ciência Rural, v.51, n.3, 2021. 
The agricultural data in the study field show that the area of the average agricultural management is 16.33 ha and the ratio of the owned land to the total land is around $74 \%$ while almost half of the managers of the agricultural holdings $(42.44 \%+7.40 \%)$ are satisfied from what their job (agricultural activity). Of the agricultural holdings, $4.49 \%$ deals only with animal farming, $30.13 \%$ deals only with vegetative production and $65.38 \%$ deals with both vegetative and animal production activities (Table 3).

When the economic variables are reviewed, it is found out that $44 \%$ of the revenues of the agricultural holdings come from agriculture and almost $3 / 4$ of the managers of the agricultural holdings find themselves to have medium level of income (Table 3).

One of the most important behaviours of the managers of the agricultural holdings with regards to intrinsic motivation was considered to be the risk behaviours and it was reported that almost $40 \%$ of the managers of the agricultural holdings liked to take risks (Table 3).

Despite the fact that the number of "baby boomers" employees in the labour market has substantially reduced, the weight of this generation still exists in the agricultural holdings that carry out agricultural activities. Aging is an important problem in Turkey particularly in the rural area and in the agricultural sector, and it is expressed that it is necessary more individuals from the generations $\mathrm{X}$ and $\mathrm{Y}$ in the sector while political measures for this purpose are being taken (KAN et al., 2018a; KAN et al., 2018b; KAN et al. 2019). The facts that every generation has its unique qualities and that they differentiate from each other indicate that there will be changes in the professional and organizational commitments of new individuals. Currently, old generations spend efforts to convey their experiences and train successors who will replace them and fill their void. Well, will the trained successors really fill the void of the old generations and have the qualities to replace them? Will conveying professional experience provide sufficient criteria for the new ones? Will the new generations be readily committed to their organizations or professions like the old generations were and will they work in the same work or sector for a long time? These are the questions frequently asked by researchers for the purpose of finding a solution. The reason behind this questioning is the fact that the individuals of new generation have higher expectation from work and from life compared to the old generation and don't really like working with revolts against authority (ADIGÜZEL et al., 2014). It is more difficult to keep the new generation at work and in the work place, to have them embrace the goals, objectives and problems of the workplace and to ensure their motivation in the work place compared to the old generation. Therefore, the managers and agricultural holdings need to examine the desires, needs and expectations of the new generation.

There are no studies directly on the management of the agricultural activities between generations in both Turkey and international area and the existing studies are usually on the professional and organizational commitments of individuals. The study by CHEN \& LIAN (2015) showed that the employees of $\mathrm{Y}$ Generation assigned more importance to both internal and external rewards compared to the previous generations. Similarly, the study of MICHEAL (2014) indicated that the Y Generation was more intrinsically motivated than the X Generation. The study by KELEŞ (2011) revealed that the motivation of the Y Generation would be positively affected if they are encouraged to produce innovative ideas and if their contributions to the operations are appreciated. KERSE (2016) reported that there were no statistically significant differences between the X Generation and Y Generation in both their levels of normative, persistent and emotional commitment and in their levels of embracing intrinsic and extrinsic motivation instruments.

As shown, there is no consensus on the findings to reveal the differences between the generations. This indicated that many factors might be effective behind the difference between generations and that there may be regional differences as well. As a result of our study, the relation between the IMC Scale and age of household head was shown in figure 2. The variance of IMC groupings between generations was examined and no statistically significant relation was reported after the Chi-square Analysis ( $\chi$ : $3.12 ; \mathrm{p}$ : 0.79). Accordingly, the change in the IMC groupings between the Traditional, Baby Boomer, X and Y generations doesn't vary in a statistically significant manner. This shows that there are high interactions between generations in the agricultural holdings and that the new generations ( $\mathrm{X}$ and $\mathrm{Y}$ ) carry out agricultural activities in line with the recommendations of the other generations (Baby Boomer and Traditional). This argument is proven by the fact that $50,49 \%$ of the owners of the agricultural holdings, who were interviewed during the study, provided the answer of "ancestral occupation" to the question about the reason of dealing with agriculture.

Another socio-demographic variable the relation of which with the IMC level was examined in 


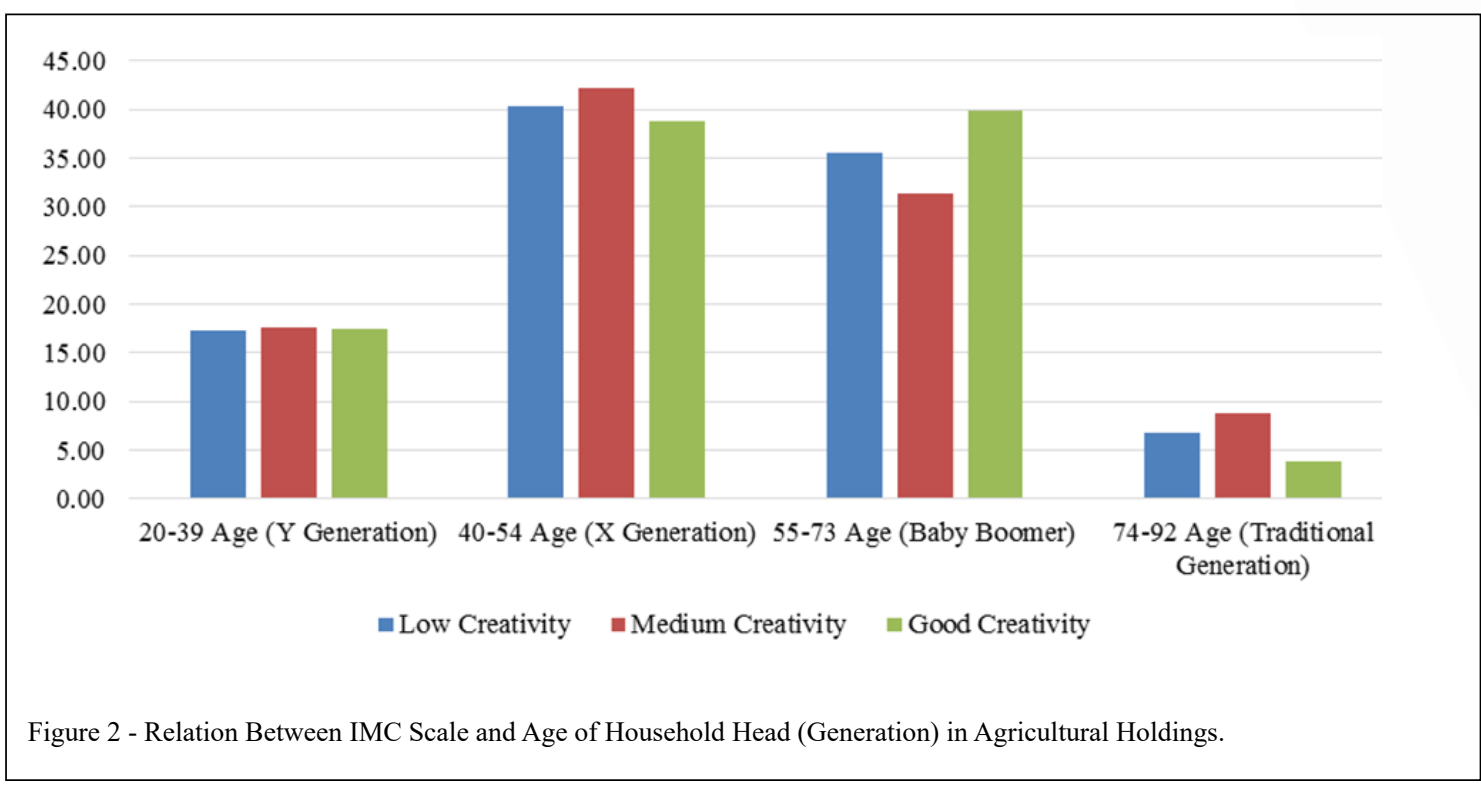

the study is the education level of the managers of the agricultural holdings. In the table 4, a statistically significant relation was reported between the IMC level and the education level with the confidence limit of $95 \%$. Table 4 shows that the individuals with the lowest education and those with the highest education have low level of IMC while those with the other learning levels have medium and high levels of IMC. Intrinsic motivations of individuals for creativity are expected to increase as the education level increases. Individuals with low education level are expected to have low IMC levels. However, the low IMC level of particularly the individuals with university education can be associated with the fact that they don't have a performance with professional creativity since they don't have a high education on agriculture. In fact, the majority of the individuals with education level dealing with agriculture in Turkey consisted of the individuals from different occupation groups. This revealed the fact that the agricultural occupation is not embraced by those with an education in agriculture but those with a different occupation. The insufficient agricultural knowledge of those with a different occupation hinders creative outcomes in the profession of agriculture.

The study examined the relation between the IMC levels and social security status of the managers of agricultural holdings and a statistically significant relation was reported between the two variables with a confidence limit of $95 \%$ as a result of the Chi-square analysis (Table 5). Individuals without a social security had low IMC levels as expected. Individuals without any social security feel uncomfortable and are therefore expected to have low intrinsic motivation for creativity. However, the

Table 4 - Relation Between IMC Level and Education Level of Household Head in Agricultural Holdings.

\begin{tabular}{|c|c|c|c|c|c|c|}
\hline \multirow[t]{2}{*}{ Education Level } & \multicolumn{2}{|c|}{--------Low Creativity---------- } & \multicolumn{2}{|c|}{------Medium Creativity------ } & \multicolumn{2}{|c|}{--------Good Creativity-------- } \\
\hline & Count & $\%$ & Count & $\%$ & Count & $\%$ \\
\hline Illiterate & 10 & 58.82 & 4 & 23.53 & 3 & 17.65 \\
\hline Primary School & 69 & 32.39 & 66 & 30.99 & 78 & 36.62 \\
\hline Secondary School & 13 & 22.81 & 24 & 42.11 & 20 & 35.09 \\
\hline University & 10 & 47.62 & 9 & 42.86 & 2 & 9.52 \\
\hline Chi Square Value: 14.86 & $\mathrm{p}: 0.02$ & H0: Decline & & & & \\
\hline
\end{tabular}

Ciência Rural, v.51, n.3, 2021. 
Table 5 - Relation Between IMC Scale and Social Security of Household Head in Agricultural Holdings.

\begin{tabular}{|c|c|c|c|c|c|c|}
\hline \multirow[t]{2}{*}{ Social Security } & \multicolumn{2}{|c|}{---------Low Creativity---------- } & \multicolumn{2}{|c|}{------Medium Creativity-------- } & \multicolumn{2}{|c|}{--------Good Creativity------- } \\
\hline & Count & $\%$ & Count & $\%$ & Count & $\%$ \\
\hline No Social Security & 17 & 16.67 & 8 & 7.77 & 16 & 15.53 \\
\hline Social Securtiy For Farmers & 46 & 45.10 & 34 & 33.01 & 34 & 33.01 \\
\hline Others & 39 & 38.24 & 61 & 59.22 & 53 & 51.46 \\
\hline Chi Square Value: 10.96 & P: 0.03 & & & & & \\
\hline
\end{tabular}

study found considerably high ratio of individuals without social security having low IMC levels. This is caused by the structural situation of the agricultural sector. Low income levels of individuals dealing with agriculture cause them to have problems in social security issues. Therefore, these individuals try to increase their intrinsic motivations to find creative solutions so that they can get more revenue. What is interesting is that individuals who accept agriculture as a profession and have Farmers social security registration have low IMC levels. This indicated structural problems of agriculture in Turkey. Particularly the low education levels of individuals in the agricultural sector, the fact that individuals cannot acquire creativity skills in educational institutions, low income level in the agricultural sector, high risks in the agricultural sector and reluctance of the producers to take risks are important structural problems. Therefore, individuals who accept agriculture to be their main occupation don't have high intrinsic motivation. Individuals who work in other sectors and choose agriculture as their secondary occupation; and therefore, have non-agriculture social security service have higher level of creativity. This is believed to be directly associated with income since these individuals have non-agricultural income providing them with a confidence which positively contributes to the increase in IMC levels. The reasons behind the relation between the IMC level and Social Security are proven by the facts that the individuals with social security in non-agricultural areas define themselves to be good $(\% 55,56)$ in the level of subjective poverty compared to the other groups and that the non-agricultural incomes of this group are higher $(59,03 \%)$ than other groups.

Table 6 demonstrates the relations between the agricultural variables and IMC levels of the owners of agricultural holdings in the field of the study. According to table 6 , there is no statistically significant relation as a result of the Variance Analysis between the variables changing the business size of the agricultural holdings (Own area, Rented

Table 6 - Relation Between IMC Scale and Some of Agricultural Variables in Agricultural Holdings.

\begin{tabular}{|c|c|c|c|c|c|}
\hline Agricultural Variables & $\begin{array}{c}\text { Low } \\
\text { Creativity }\end{array}$ & $\begin{array}{l}\text { Medium } \\
\text { Creativity }\end{array}$ & $\begin{array}{c}\text { Good } \\
\text { Creativity }\end{array}$ & Total & F Value \\
\hline & Mean & Mean & Mean & Mean & \\
\hline Own Area (Ha) & 11.39 & 11.20 & 13.88 & 12.16 & 0.92 \\
\hline Rented Area (Ha) & 2.97 & 4.46 & 5.14 & 4.18 & 1.07 \\
\hline Irrigated Area (Ha) & 3.03 & 2.07 & 4.42 & 3.17 & $2.43^{*}$ \\
\hline Total Area (Ha) & 14.36 & 15.65 & 19.03 & 16.34 & 1.25 \\
\hline Large Ruminant (Count) & 18.62 & 13.01 & 15.76 & 15.80 & 0.65 \\
\hline Small Ruminant (Count) & 36.15 & 23.40 & 22.76 & 27.47 & 0.36 \\
\hline Crop Production Experience (Year) & 25.75 & 27.46 & 26.07 & 26.41 & 0.42 \\
\hline Animal Production Experience (Year) & 26.03 & 23.74 & 23.82 & 24.60 & 0.68 \\
\hline Total Working Day in Agricultural Activities (Days) & 140.14 & 135.84 & 151.80 & 142.66 & 0.75 \\
\hline The Share of Agricultural Income & 49.68 & 45.77 & 35.58 & 43.70 & $6.07^{* * *}$ \\
\hline
\end{tabular}

Statistically important at ${ }^{*} 90 \%,{ }^{* *} 95 \%, 99 \%$ confidence levels 
area, Total Area, Large Ruminant, Small Ruminant). However, there is a statistically significant relation between the size of irrigated land of the holdings and the IMC levels. The existence of irrigated land is an indicator of richness in agriculture and holdings with more irrigated land have better IMC levels. The same situation is also seen in the variable of the share of agricultural income in the total income. As mentioned before, the revenues obtained from the agricultural production in Turkey are lower compared to the other sectors and therefore the owners of agricultural holdings with more non-agricultural income have better IMC levels. In addition, no statistically significant relation was found between the duration of experience in agriculture (vegetative and animal) and the IMC levels.

Agricultural holdings contain important structural differences compared to the businesses in other sectors. Particularly in developing countries like Turkey, where agriculture and agriculturebased industry have high share in GDP, agricultural operations are mainly carried out in small family holdings where employees are mainly family labour force. Therefore, elements including motivation and creativity in holdings are important not for the employees but for the head of the household who is also the manager of the holding. Considering that motivation and creativity involve a positively related consecutive process, high motivation will also have positive effect on creativity (AMAIBLE, 1998, ALDER, 2004; RIZA, 2004; BURLESON, 2005; AYDEN \& ISGUZAR, 2016). AMAIBLE (1998) talks about field knowledge (expertise), creative thinking and internal motivation as the three components of creativity and states that creativity will be hindered if any of them is missing. She emphasized the importance of motivation arguing that it is the element that activates creative thinking and expertise. It is known that there are internal and external factors increasing motivation. Income is stated to be one of the motivations instruments while the significance of it varies by person and institution (CAN, 2002). A motivated employee will have a higher level of reaching organizational objectives and this would greatly increase the success of the business (KOÇEL, 2001). Economic instruments are among the important factors used for increasing motivation. Upon physical comparison of the agricultural sector, there are important differences compared to the other sectors with regards to risks and uncertainties. Therefore, there are limited studies on the motivation of the employees in the agricultural sector in both Turkey and the world. Factors affecting the motivation of both managers and employees vary because of the fact that the agricultural sector in countries like Turkey has lower revenue level and involves more risks and uncertainties compared to the other sectors in addition to the structural differences.

As a result of the study, the relation between the subjective poverty levels and the IMC levels of the managers of the agricultural holdings in the Kırşehir province were examined and this relation was found to be statistically significant with a confidence limit of $90 \%$. With regards to subjective poverty, individuals who define themselves to have a good income were found to have better IMC levels than the individuals who define themselves to be poor. The study revealed that the subjective poverty levels in all IMC levels were higher in the medium level (Table 7 and Figure 3). This gives an information about the general condition of agriculture. In the study, the fact that the non-agricultural revenues were higher among the income resources of the agricultural employees (around 56\%, Table 3) and the fact that the revenues in the agricultural sector was lower than the other sectors causes the medium income group to have more agricultural holdings (Table 7 and Figure 3).

Believing is the first step in motivation followed by risk-taking self-confidence and awareness of one's demands and abilities (BUDAK, 2011). There are different scientific explanations about the relation between the risk-taking behaviour and creativity of individuals. Many authors in the field of economy accept that creative people have certain qualities and define them to be mainly risk taking persons (CARVER \& WHITE, 1994; KELTNER et al., 2003; LEE et al., 2004; MAINEMELIS, 2010). Many scientists argued that higher the risks more radical the creativity (BENNER \& TUSHMAN, 1993; SMITH \& TUSHMAN, 2005) while some argues that sharing a risk with a group of people increases creativity (GLOVER, 1977). Beyond agreeing on the positive relations between risk and creativity, economists have emphasized that risk attitude is a stable component of individual behaviour and that choices are not affected by contexts (DOHMEN et al. 2011; EINAV et al. 2012; VIEIDER et al. 2015). Conversely, among psychologists there is a general consensus that risk attitudes are contextspecific and that risk choices in different contexts are poorly correlated (WEBER et al., 2002).

The study reported a statistically significant relation between the IMC Scale and the risk behaviours of the agricultural producers in the province of Kirşehir. The majority of the producers in the group of low creativity consists individuals who avoid risks. The risk behaviours of individuals change as the level of creativity increases and they 
Table 7 - Relation Between IMC Scale and Income Variables of Agricultural Holdings.

\begin{tabular}{lcccccc}
\hline $\begin{array}{l}\text { Subjective } \\
\text { Poverty }\end{array}$ & \multicolumn{2}{c}{$\begin{array}{c}\text { Low } \\
\text { Creativity }\end{array}$} & \multicolumn{2}{c}{$\begin{array}{c}\text { Medium } \\
\text { Creativity }\end{array}$} & \multicolumn{2}{c}{$\begin{array}{c}\text { Good } \\
\text { Creativity }\end{array}$} \\
\hline Poor & $\mathrm{N}$ & $\%$ & $\mathrm{~N}$ & $\%$ & $\mathrm{~N}$ & $\%$ \\
\hline Medium & 77 & 7.69 & 3 & 2.91 & 5 & 4.85 \\
\hline Good & 19 & 18.27 & 15 & 14.56 & 29 & 28.16 \\
\hline Chi Square Value: 8.99 & \multicolumn{2}{l}{ P: 0.06} & \multicolumn{2}{l}{$\mathrm{H}_{0:}$ Declined } \\
\hline
\end{tabular}

tend to take more risks (Table 8 and Figure 4). This complies with the theories of the economists. However, the high ratio of the individuals avoiding risks among the individuals in the group of good creativity can be associated to the insufficient organizational behaviour of the individuals in the agricultural sector in Turkey and to the effect of the national economic fluctuations. This complies with the thesis of Glover (1977) who argued that creativity will be increased if risks are shared with a group of people.

\section{CONCLUSION}

Innovation is one of the most important ways of survival in today's competitive environment. The agricultural sector is the most important sector

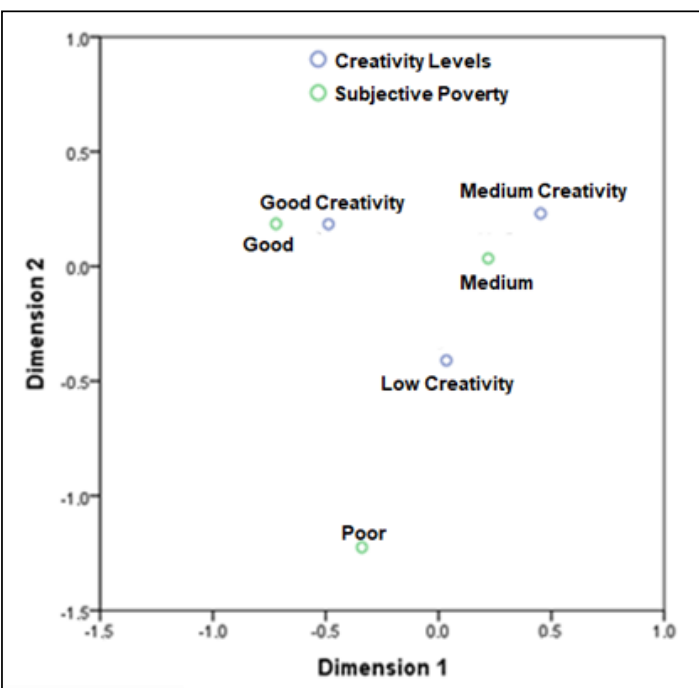

Figure 3 - Relation Between IMC Scale and Income Variables of Agricultural Holdings.
Table 8 - Relation Between IMC Scale and Risk Attitude of Household Head in Agricultural Holdings.

\begin{tabular}{lcclccc}
\hline Risk Level & \multicolumn{2}{c}{$\begin{array}{c}\text { Low } \\
\text { Creativity }\end{array}$} & \multicolumn{2}{c}{$\begin{array}{c}\text { Medium } \\
\text { Creativity }\end{array}$} & \multicolumn{2}{c}{$\begin{array}{c}\text { Good } \\
\text { Creativity }\end{array}$} \\
\hline & $\mathrm{N}$ & $\%$ & $\mathrm{~N}$ & $\%$ & $\mathrm{~N}$ & $\%$ \\
\hline Risk Lower & 29 & 28.16 & 43 & 41.75 & 47 & 45.63 \\
\hline Risk Neutral & 20 & 19.42 & 11 & 10.68 & 9 & 8.74 \\
Risk Averse & 54 & 52.43 & 49 & 47.57 & 47 & 45.63 \\
\multicolumn{2}{l}{ Chi Square Value: 10.17} & P: 0.03 & \multicolumn{2}{l}{$\mathrm{H}_{0}$ : Declined } \\
\hline
\end{tabular}

playing a role to meet the primary needs of people. Unfortunately, in developing countries such as Turkey, the most important basic problem of the sector is the effort by everyone, whether or not having specialism about the matter, to take part in the sector. This causes structural problems in the sector. Traditional structure and mentality prevail in the sector which includes several large and small businesses. In such a structure, the key to success and to play an important role in the sector is through obtaining opportunities in the competition through innovative ways. The path to innovation goes through creativity, and for the creativity, the motivation (especially intrinsic motivation) is key component. The process of fostering creativity for innovation is based mainly on building intellectual capital that

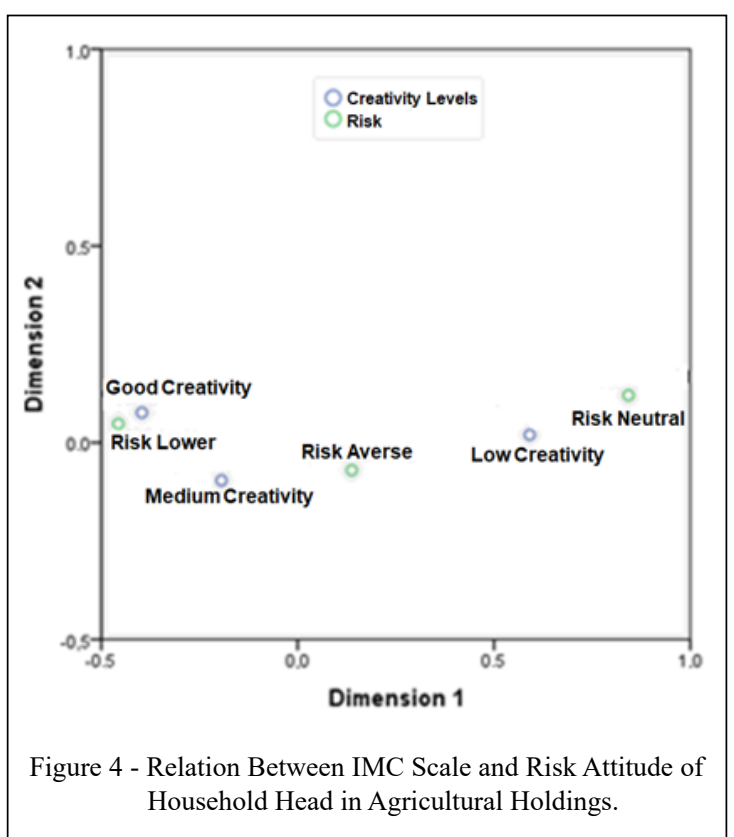

Ciência Rural, v.51, n.3, 2021. 
will provide the competencies and capabilities for improved performance within the organization.

Turkey ranks among the first countries in Europe and in the world with respect to the value of agricultural production. However, the structural problems have a negative effect on the efficiency and competition of the sector. Despite the fact that the number of the employees in the agricultural sector from the "Baby Boomers" generation decreased considerably, the weight of this generation in the agricultural holdings carrying out agricultural operations still exists. Aging particularly in the rural area and in the agricultural sector in Turkey is an important problem. The adaptation of the $\mathrm{Y}$ generation in the agricultural sector is important for the future of the sector. New generations having greater advantages compared to the other generations with respect to innovation and creativity need to take measures to increase their intrinsic motivations. The finding of the study that there is no positive relation between the increase in the education level and the level of intrinsic motivation for creativity (IMC) shows us that the educated people don't have education in the agricultural sector and therefore they don't have sufficient intrinsic motivation for creativity in agriculture. This indicated the shortcomings in the education policies with respect to in creativity. The phenomena that may economically affect individuals and that may protect them against the risks in the sector were found to be effective factors for intrinsic motivation. The frequent economic fluctuations in Turkey, the fact that the agricultural sector was more affected by the economic shocks, and the fact that the agricultural sector has more risks and uncertainties compared to other sectors affect both the intrinsic and extrinsic motivations of individuals. The creativity motivation of the owners of agricultural holdings is also affect by the low level of their organizational behaviours.

In conclusion, almost all of the developed countries in the world also managed to develop the agricultural sector. The way of sustainable positioned in the global market in terms of agriculture sector for emerging countries such as Turkey passes through the increase of competitiveness. Competitiveness is possible with the producers who are confident and risk-taking (intrinsic motivation is high) and, if necessary, is supported via the supporting elements that do not disrupt the market, and externally motivated in the environment where positive externalities are formed. In reality we need both intrinsic and extrinsic motivation for our long term and sustained gratification and success. But firstly, intrinsic motivation is provided for the producers before than extrinsic motivation to put your foot down firmly. An intrinsic motivational environment can actually change a person's perceived perceptions of self and guide them into changing their behaviour. Both intrinsic and extrinsic motivations of individuals for creativity in agriculture should be increased by the solution of structural problems including organization in agriculture, social security, education, inclusion of young individuals in the agricultural sector, establishment of an entrepreneurship culture and removal of economic uncertainties. As a result, an agricultural sector having innovative approaches will become a highly competitive sector in the international area. Special agricultural and rural development policies in this matter are essential for the sustainability of the sector. Especially this is necessary for the emerging economies and the countries depending mainly to agriculture and agriculture based sectors.

\section{DECLARATION OF CONFLICT OF INTERESTS}

The authors declare no conflict of interest. The founding sponsors had no role in the design of the study; in the collection, analyses, or interpretation of data; in the writing of the manuscript, and in the decision to publish the results.

\section{ACKNOWLEDGEMENTS}

We would like to thank the farmers of Kırşehir ProvinceTurkey who devoted their valuable time to this study and meticulously answered the questionnaires we prepared in our study.

\section{AUTHORS' CONTRIBUTIONS}

All authors contributed equally for the conception and writing of the manuscript. All authors critically revised the manuscript and approved of the final version.

\section{REFERENCES}

ADIGÜZEL, O., et. al. Kuşakların değișen yüzü ve Y Kuşağı ile ortaya çıkan yeni çalışma tarzı: Mobil yakalılar, Süleyman Demirel Üniversitesi Sosyal Bilimler Enstitüsü Dergisi, v.19, p.165-182. 2014. Available from: <https://dergipark.org.tr/en/download/articlefile/215113>. Accessed: Jan. 23, 2020. (Electronic publication).

AHİKA (Ahiler Kalkınma Ajansı). TR71 Düzey 2 Bölgesi Tarım ve Hayvancılık Sektöründe Mevcut Durum ve 2014-2023 Yılları Stratejileri ve Hedefleri Raporu. 2013. Available from: <https:// www.ahika.gov.tr/assets/upload/dosyalar/ahika_2013_tr71bolgesi-tarim-ve-hayvancilik-sektorunde-mevcut-durum-ve-20142023-stratejileri-ve-hedefleri-raporu.pdf $>$. Accessed: Jan. 29, 2020.

ALDER, H. Yaratıcı Zeka, (Çev. M. Zaman, C. Avşar ), Hayat Yayıncılık, İstanbul. 2004.

Ciência Rural, v.51, n.3, 2021. 
ANDERSON, N. et. al., Innovation and creativity in organizations, Journal of Management. v.40, p.1297-1333. 2014. doi: $10.1177 / 0149206314527128$.

AYDEN, C \& ISŞGÜZAR, S. Üniversite öğrencilerinin yaratıcıllk düzeyleri ve motivasyonları arasındaki ilişkiyi incelemeye yönelik araştırma. The Journal of International Social Sciences, v.26, n.2, p.201-218. 2016. Available from: <https://dergipark.org. tr/en/download/article-file/355143>. Accessed: Jan. 23, 2020. (Electronic publication).

BARIŞIK, S. Yenilik, yenilik oluşumunda devletin rolü, Verimlilik Dergisi, Milli Prodüktivite Merkezi Yayını, v.4, p.7-24. 2001.

BARKER, A. Yenilikçilik Deyince Ne Anlıyoruz?, Yenilikçiliğin Simyası, (Çev. Ahmet Kardam), İstanbul: MESS Yayınları. p.2137. 2001.

BENNER, M. J., \& TUSHMAN, M. L. Exploitation, exploration, and process management: The productivity dilemma revisited. Academy of Management Review, v.28, n.2, p.238-256. 2003. Available from: <http://www.jstor.org/stable/30040711>. Accessed: Jan. 23, 2020. (Electronic publication).

BUDAK, F. İç Motivasyon. Available from: <https://www. tavsiyeediyorum.com $/$ makale_7315.htm $>$. 2011. Accessed: Jan. 29, 2020.

BURLESON, W. Developing creativity, motivation, and selfactualization with learning systems. Int. J. Human-Computer Studies, v.63, p.436-451. 2005. Available from: <http://www.jstor. org/stable/30040711>. Accessed: Jan. 23, 2020. doi: 10.1016/j. ijhcs.2005.04.007.

CAN, H. Organizasyon ve Yönetim, 6. Bask1, Siyasal Kitabevi, Ankara. 2002.

CARVER, C. S., \& WHITE, T. L. Behavioral inhibition, behavioral activation, and affective responses to impending reward and punishment: the BIS/BAS scales. Journal of personality and social psychology, v.67, n.2, p.319, 1994. Available from $<$ https://www.researchgate.net/publication/232481813_Behavioral Inhibition_Behavioral_Activation_and_Affective_Responses_to_ Impending Reward and Punishment The BISBAS Scales>. Accessed: Jan. 26, 2020. (Electronic publication).

CHEN, J. \& LIAN, R. Generational differences in work values in China. Social Behavior and Personality, v.43, n.4, p.567-568. 2015. Available from: $<$ https://www.sbp-journal.com/index.php/sbp/article/ view/4515>. Accessed: Jan. 26, 2020. doi: 10.2224/sbp.2015.43.4.567.

CHIRKOV, V., et al. Differentiating autonomy from individualism and independence: a self-determination theory perspective on internalization of cultural orientations and well-being. Journal of personality and social psychology, v.84, n.1, p.97-110.2003. Available from: <https://psycnet.apa.org/doiLanding?doi=10 1037\%2F0022-3514.84.1.97>. Accessed: Jan. 26, 2020. doi: 10.1037/0022-3514.84.1.97.

CROPLEY, D. H. The role of creativity as a driver of innovation. Available from: <https://www.researchgate.net/ publication/224679521_The_Role_of_Creativity_as_a_Driver_of Innovation>. 2006, Accessed: Aug. 31, 2020. (Electronic publication).

DECI, E. L., \& RYAN, R. M. Intrinsic motivation and selfdeterminaton in human behaviour. New York: Plenum. 1985.
DECI, E. L., et. al. Need satisfaction and the self-regulation of learning. Learning and Individual Differences, v.8, p.165-183. 1996. Available from: <http://selfdeterminationtheory.org/SDT/ documents/1996_DeciRyanWilliams_LID.pdf>. Accessed: Aug. 31, 2020. (Electronic publication).

DEMIREL, Y., \& SEÇKIN, Z. Bilgi ve bilgi paylaşımının yenilikçilik üzerine etkileri. Çukurova Üniversitesi Sosyal Bilimler Enstitüsü Dergisi, v.17, n.1, p.189-202. 2008.

DOHMEN, T., et. al. Individual risk attitudes: measurement, determinants, and behavioral consequences. Journal of the European Economic Association, v.9, n.3, p.522-550. 2011. Available from: <https://onlinelibrary.wiley.com/doi/abs/10.11 11/j.1542-4774.2011.01015.x>. Accessed: Aug. 31, 2020. doi: 10.1111/j.1542-4774.2011.01015.x.

DÜZGÜNEŞ, O., et. al. Statistics Methods I, 1st Ed. University of Ankara Publishing's of Agriculture Faculty, Ankara, Turkey. 1983.

EINAV, L., et. al. How general are risk preferences? Choices under uncertainty in different domains. American Economic Review, v.102, n.6, p.26-38. 2012. Available from: <https://www.aeaweb. org/articles?id=10.1257/aer.102.6.2606>. Accessed: Aug. 31, 2020. doi: 10.1257/aer.102.6.2606.

ENGEL, P. G. H. Facilitating Innovation an Action-Oriented Approach and Participatory Methodology to Improve Innovative Social Practice in Agriculture. 1994. Available from: <http:// library.wur.nl/WebQuery/wurpubs/28932>. Accessed: Jan. 29, 2020. (Electronic publication).

GLOVER, J. A. Risky shift and creativity. Social Behavior and Personality: An International Journal, v.5, n.2, p.317-320. 1977. Available from: <https://www.sbp-journal.com/index.php/ sbp/article/view/187>. Accessed: Jan. 29, 2020. doi: 10.2224/ sbp.1977.5.2.317.

KAN M., et. al. Kırsal Alanda Tarımda Yaşlanmayı Önlemek İçin Genç Çiftçi Desteği Perspektifinden Bir Bakış. Uluslararası Katılımlı XIII. Ulusal Tarım Ekonomisi Kongresi, p.44. 2018a.

KAN A., et. al. Evaluation of young farmers project support program in terms of agri-entrepreneurship in Turkey. Pakistan Journal of Agricultural Sciences, v.55, n.4, p.1021-1031. 2018b. Available from: <https://www.pakjas.com.pk/>. Accessed: Jan. 29, 2020. doi: 10.21162/PAKJAS/18.7321.

KAN M., et. al. Young farmers in agriculture sector of Turkey: young farmers support program. Journal of Agricultural Science and Technology, v.21, n.1, p.15-26. 2019. Available from: <https:// jast.modares.ac.ir/article-23-16634-en.pdf>. Accessed: Jan. 29, 2020. (Electronic publication).

KART, M. E., \& GÜLDÜ, Ö. Self-determination scale: the adaptation study. Ankara University Journal of Faculty of Educational Sciences, v.41, n.2, p.187-207. 2008. Available from: $<$ https://dergipark.org.tr/en/pub/auebfd/issue/38393/445254>. Accessed: Jan. 29, 2020. doi: 10.1501/Egifak_0000001129.

KASSIE, M., et al. Adoption of interrelated sustainable agricultural practices in smallholder systems: Evidence from rural Tanzania. Technological forecasting and social change, v. 80 , p.525-540. 2013. Available from: <sciencedirect.com/science/article/pii/ S0040162512001898>. Accessed: Jan. 29, 2020. doi: 10.1016/j. techfore.2012.08.007. 
KELEŞ, H. N. Y kuşağı çalışanlarının motivasyon profillerinin belirlenmesine yönelik bir araştırma. Organizasyon ve Yönetim Bilimleri Dergisi, v.3, n.2, p.129-139. 2011. Available from: $<$ https://dergipark.org.tr/tr/pub/oybd/issue/16338/171055>. Accessed: Jan. 29, 2020.

KELTNER, D., et. al. Power, approach, and inhibition. Psychological Review, v.110, n.2, p.265. 2003. Available from: $<$ https://psycnet.apa.org/record/2003-00307-004>. Accessed: Jan. 29, 2020. doi: 10.1037/0033-295X.110.2.265.

KERSE, G. motivasyon araçlarının örgütsel bağlılık üzerindeki etkisi: kamu kurumlarındaki $\mathrm{X}$ ve $\mathrm{Y}$ kuşağ 1 karşılaştırması. Business \& Management Studies: An International Journal, v.4. n.1, p.1-23. 2016. Available from: $<$ https://bmij. org/index.php/1/citationstylelanguage/get/modern-languageassociation?submissionId=169>. Accessed: Jan. 29, 2019. doi: 10.15295/bmij.v4i1.125

KESİCI, T. \& Z. KOCABAŞ. Biostatistics. Ankara University Faculty of Pharmacy. Publication number: 94, Ankara, Turkey. 2007.

KOÇEL, T. İșletme Yöneticiliği. 8. Baskı, Beta Masım Yayım Dağıtım A. Ş. İstanbul. 2001.

KOWAL, J., \& FORTIER, M. S. Motivational determinants of flow: Contributions from self determination theory. The Journal of Social Psychology, v.139, n.3, p.355-368. 1999. Available from: <https://www.tandfonline.com/doi/ abs/10.1080/00224549909598391>. Accessed: Jan. 29, 2020. doi: $10.1080 / 00224549909598391$.

KTOİM (Kırşehir Agriculture and Forestry Province Directorate). Agriculture and Forestry Information on Kırşehir Province. 2019. Available from: $<$ https://kirsehir.tarimorman.gov.tr/Menu/9/ Il-Tanitim\#>. Accessed: Jan. 29, 2019.

LEE, F., et. al. The mixed e ects of inconsistency on experimentation in organizations. Organization Science, v.15, n.3, p.310- 326. 2004. Available from: <http://www.jstor.org/stable/30034735>. Accessed: Jan. 29, 2020. (Electronic publication).

LIU, N., et al. Motivational mechanisms of employee creativity: a meta-analytic examination and theoretical extension of the creativity literature. Organizational Behavior and Human Decision Processes, v.137, p.236-263. 2016. Available from: $<$ https://www.sciencedirect.com/science/article/abs/pii S0749597816304794>. Accessed: Jan. 29, 2020. doi: 10.1016/j. obhdp.2016.08.001.

LUTHANS, F. Organizational behavior. McGraw-Hill International Editions. 1992.

MAINEMELIS, C. Stealing fire: Creative deviance in the evolution of new ideas. Academy of Management Review, v.35, n.4, p.558578. 2010. Available from: <http://www.mainemelis.com/userfiles/ articles/AMR2010_94848371.pdf>. Accessed: Jan. 28, 2020. (Electronic publication)

MOLLER, A. C., RYAN, R. M. \& DECI, E. L. Self-determination theory and public policy: Improving the quality of consumer decisions without using coercion. Journal of Public Policy \& Marketing, v.25, p.104-116. 2006. Available from: <https:// journals.sagepub.com/doi/10.1509/jppm.25.1.104>. Accessed: Jan. 28, 2020. doi: 10.1509/jppm.25.1.104
MWAIJANDE, N. S. Smallholder Farmers' Motivations for Adopting Sustainable Intensification in Tanzania. MSc Thesis Farming Systems Ecology, Wageningen University \& Research, The Netherland. Available from: <https://edepot.wur.nl/416390>. Accessed: Jul. 07, 2020.

NELSON, D. L., \& QUICK, J. C. Organizational behaviour: foundation, realities and challenges. Australia: Thomson SouthWestern. 2003.

\section{OFFICIAL GAZETTE. Agriculture Law in Turkey. Available from: <https:/www.resmigazete.gov.tr/} eskiler/2006/04/20060425-1.htm>. Accessed: Jul. 06, 2020.

OĞUZ C., et. al. Poverty in Agricultural and Rural Community: A Case Study from Konya, Turkey. I. International Interdisciplinary Social Inquiry Conference, v.1, p.1103-1113. 2012.

OLHAN, E., et al., Effects of agricultural activities in Seyfe Wetland. Sci. Res. Essays. v.5, p.9-14. 2010. Available from: $<$ https://academicjournals.org/journal/SRE/article-full-textpdf/E843CE615990>. Accessed: Jan. 29, 2020. doi: 10.5897/ SRE.9000420 (Electronic publication).

OZDEMIR, H. O. \& KAN, A., Risk behaviours of agricultural holdings managers on management and decision making process in agricultural production; Kirşehir province case. J. Glob. Innov. Agric. Soc. Sci. v.8, n.1. p.35-42. 2020. Available from: $\quad<$ https://www.researchgate.net/publication/340377945 RISK_BEHAVIOURS_OF_AGRICULTURAL_HOLDINGS MANAGERS ON MANAGEMENT AND DECISION MAKING_PROCESS_IN_AGRICULTURAL_PRODUCTION KIRSEHIR PROVINCE CASE $>$. Accessed: Jan. 29, 2020. doi: $10.22194 / \mathrm{JG}$ IASS/8.880.

OZDEMIR, H. O. et al., The factors affecting psychological empowerment levels of entrepreneurs in agricultural holdings of Kirsehir Province, Turkey. Pak. J. Agri. Sci., v.57, n.3, p.911920. 2020. Available from: <https:/www.researchgate.net/ publication/342150612_The_Factors_Affecting_Psychological_ Empowerment Levels of Entrepreneurs in Agricultural Holdings_of_Kirsehir_Province_Turkey>. Accessed: Jan. 29, 2020. doi: 10.21162/PAKJAS/20.10005.

RIZA, E. T., Yaratıcılığı Geliştirme Teknikleri, Kanyılmaz Yayınevi, İzmir. 2004.

RIGBY, C. S., et. al. Beyond the intrinsic-extrinsic dichotomy: Selfdetermination in motivation and learning. Motivation and Emotion, v.16, p.165-185. 1992. Available from: <https://link. springer.com/article/10.1007/BF00991650>. Accessed: Jan. 29, 2020. doi: 10.1007/BF00991650.

RYAN, R. M., \& DECI, E. L. Self-determination theory and the facilitation of intrinsic motivation, social development, and wellbeing. American Psychologist, v.55, n.1, p.68-78. 2000. Available from: <https://pubmed.ncbi.nlm.nih.gov/11392867/>. Accessed: Jan. 29, 2020. doi: 10.1037110003-066X.55.1.68.

ROBBINS, S. P. Organizational behavior: concepts, controversies, applications. Englewood Cliffs. NJ: Pearson Education Inc. Seventh Edition. 1996.

ROBBINS, S. \& JUDGE, T. Comportamiento organizacional [Organizational behavior] ( $15^{\mathrm{a}}$ ed.). México: Pearson Prentice Hall. 2013. 
SMITH, W. K., \& TUSHMAN, M. L. Managing strategic contradictions: A top management model for managing innovation streams. Organization Science, v.16, n.5, p.522-536. 2005. Available from: <https://pubsonline.informs.org/doi/abs/10.1287/ orsc.1050.0134>. Accessed: Jan. 29, 2020. doi: 10.1287/ orsc. 1050.0134 .

SUBAŞI, O. S., \& ÖREN, M. N. Türkiye'de tarımsal Ar-Ge harcamaları ve tarımsal büyüme ilişkileri. Akdeniz Üniversitesi Ziraat Fakültesi Dergisi, v.26, n.2, p.99-104. 2013. Available from: $\quad<$ https://dergipark.org.tr/tr/download/article-file/17964>. Accessed: Jan. 23, 2020. (Electronic publication).

SUNGUR, O., KOÇ, R., \& DULUPÇU M. A. Antalya'da tarım ve tarımla ilişkili firmaların inovasyon ve yerel aktörlerle işbirliği faaliyetlerinin analizi. Tarım Ekonomisi Dergisi, v.20, n.1-2, p.115. 2014.

TIERNEY, P. et. al. An Examination of Leadership and Employee Creativity: The Relevance of Traits and Relationships, Personnel Psychology, v.52, n.3, p.591-620. 1999. Available from: <https:// onlinelibrary.wiley.com/doi/abs/10.1111/j.1744-6570.1999. tb00173.x>. Accessed: Jan. 29, 2020. doi: 10.1111/j.17446570.1999.tb00173.x.

UYAN, B. Tarımın Küresel Güç Sistemine Dönüşme Sürecinde İnovasyonun Rolü, İktisadi Yenilik Dergisi, v.5, n.2, p.83-93. 2018.

VERHEES, F. J. H. M., \& MEULENBERG, M. T. G. Market orientation, innovativeness, product innovation, and performance in small firms, Journal of Small Business Management, v.42, n.2, p.134-154. 2004. Available from: <https://onlinelibrary.wiley.
com/doi/abs/10.1111/j.1540-627X.2004.00102.x>. Accessed: Jan. 29, 2020. doi: 10.1111/j.1540-627X.2004.00102.x.

VIEIDER, F. M., et. al.. Common components of risk and uncertainty attitudes across contexts and domains: Evidence from 30 countries. Journal of the European Economic Association, v.13, n.3, p. 421-452. 2015. Available from: $<$ https://academic.oup. com/jeea/article-abstract/13/3/421/2319769? redirectedFrom=fullt ext>. Accessed: Jan. 29, 2020. doi: 10.1111/jeea.12102.

WEBER, E. U. et. al. A domain-specific risk-attitude scale: Measuring risk perceptions and risk behaviors. Journal of Behavioral Decision Making, v.15, n.4, p.263-290. 2002. Available from: <https://onlinelibrary.wiley.com/doi/10.1002/ bdm.414>. Accessed: Jan. 29, 2020. doi: 10.1002/bdm.414.

WONG, S. C. \& LADKIN, A. Exploring the relationship between employee creativity and job-related motivators in the Hong Kong hotel industry. International Journal of Hospitality Management, v.27, p.426-437. 2008. Available from: <https:// www.sciencedirect.com/science/article/pii/S0278431908000029>. Accessed: Jan. 29, 2020. doi: 10.1016/j.ijhm.2008.01.001.

YAMANE, T. Temel Örnekleme Yöntemleri. Esin, A., M.A. Bakır, C. Aydın and E. Gürbüzsel (Çev.). 1st Ed. Literatür Yayıncılık, Türkiye. 2001

YUAN, F. \& WOODMAN, R. Innovative behavior in the workplace: the role of performance and image outcome expectations, Academy of Management Journal, v.53, n.2, p.323-342. 2010. Available from: <https://journals.aom.org/ doi/10.5465/amj.2010.49388995>. Accessed: Jan. 29, 2020. doi: 10.5465/AMJ.2010.49388995. 